\title{
Motivation in Online Learning Amidst Covid-19 Pandemic Era: Students' Intrinsic and Extrinsic Factors
}

\author{
Sri Gustiani ${ }^{1, *}$, Welly Ardiansyah ${ }^{1}$, Tiur Simanjuntak ${ }^{1}$ \\ ${ }^{1}$ Sriwijaya State Polytechnics \\ Corresponding author.Email: srigustiani@polsri.ac.id
}

\begin{abstract}
Student learning motivation is an important factor to produce high-quality graduates. It can grow from the inside of themselves (intrinsic) or it occurs because of from outside the students (extrinsic). This study was aimed to reveal both students' intrinsic and extrinsic factors toward their motivation in online learning during the Covid-19 Pandemic era. The sudden transformation from offline learning to online one in Sriwijaya State Polytechnic, presents internal and external motivation factors of the students. Using random sampling, there were 922 students participated in a survey questionnaire. The collected data were analysed using Self-Determination Theory of Deci and Ryan (1985). It was revealed that the intrinsic factors (interest, enjoyment, satisfaction) influence the student learning motivation toward their online learning by $81.2 \%, 74.6 \%$ and $92.5 \%$. Only the intrinsic factor of encouragement is lower than the counterparts $(44 \%)$. While the influences of extrinsic factors on student learning motivation toward their online learning are classified good; identified regulation (79.85), integrated regulation (77.2\%), introjected regulation $(73.1 \%)$, and external regulation (72.8). Related to amotivation factors, students had no serious amotivation factors in their online learning during the Covid-19 pandemic era. The motivations in online learning are positively correlated with students' curiosities to learn new knowledge and enjoy new learning experiences (intrinsic motivation) and are influenced by regulation and environmental condition (extrinsic motivation).
\end{abstract}

Keywords: Covid-19 Pandemic Era, Intrinsic and Extrinsic Motivation, Online Learning, Students' Motivation

\section{INTRODUCTION}

As a result of physical distancing program to decrease the Covid-19 pandemic outbreak, the Ministry of Education and Culture of the Government of Indonesia Republic has regulated online learning processes to all education levels in Indonesia [1]. This quick learning methods change learning from traditional face-to-face method to remotely digital method. It was proven to have both advantages and disadvantages by some studies. On one hand, online learning was beneficial for students because it increased their computer skills and technology savvy. They were highly exposed to digital teaching and learning programs regardless time and place with high virtual communication among them [2][3][4][5][6][7] [8]. On the other hand, online learning was also brought some hindrances like health and financial problems.
Impairment eyesight due to high eyes intention to computer and smart phone screens; and fatigue and headache due to overload assignment in short time [3][4][7][8].

Nevertheless, the benefit and hindrances were affected by the students' motivation [8][9][10][11]. In higher education, the motivation in online learning contributed varying effects in Indonesia universities. Some students in universities were highly motivated while others lack of it, either intrinsically or extrinsically. Intrinsically, they were enthusiasm to participate in online learning due to their own ambition, resilience, and psychological condition. Meanwhile, their online learning was externally affected by environment, time, and supported facilities. 
Having debatable facts pertaining students' motivation in online learning amidst the Covid-19 pandemic era in Indonesia universities, this study was aimed to illuminate the intrinsic and extrinsic factors of students in a higher vocational institution, Sriwijaya State Polytechnic, toward their online learning. Hence, it was worth to answer the question: what are the intrinsic and extrinsic motivation levels of students in Sriwijaya State Polytechnic toward their online learning within the Covid-19 pandemic era.

\section{LITERATURE REVIEW}

\subsection{Motivation in Learning}

Motivation in learning is rooted from SelfDetermination Theory [12]. As a driving factor in learning, motivation drives learners to choose what, how, and when to learn. Learners with high motivation happily take chances to involve in challenging activities, actively engaged, and adopt any strategies to learn. They also perform better, persistent, and creative learning processes. Regardless their motivation levels, motivated learners determine their learning achievement [13][14] [15][16]. The reciprocal relation between motivation and learning has been greatly studied in various education levels. Indeed, studies about students' motivation in learning during this Covid-19 pandemic era are intense. It is due to the urgent transition to online learning in which motivation in remotely digital learning was affected by both intrinsically and extrinsically factors. Some studies unveiled that intrinsic factors more affected on students' motivation in online learning [10][17] [18][19], while others are vice versa [20][21][22][23].

\subsubsection{Intrinsic Motivation}

'Intrinsic motivation is defined as the doing of an activity for its inherent satisfaction rather than for some separable consequence' [24]. It is influenced by internal stimulus like interest, joy, or challenge that an individual poses in conducting activities for the sake of satisfaction. It is also related to ambition, aspiration, awareness, competency, physical and psychological conditions. Intrinsic motivation drives an individual to motivate in: (1) learning and gaining new knowledge like happiness in learning new knowledge; (2) experiencing the encouragement and physical joy such as enjoyment in learning interesting knowledge; and (3) undertaking challenging learning activities for instance completing challenging tasks.

\subsubsection{Extrinsic Motivation}

Extrinsic motivation as 'a construct that pertains whenever an activity is done to attain some separable outcome' [24]. It is driven by external factors like rewards or recognition from others. It is also influenced greatly by family condition, studying condition, social condition, and subsidiary facilities. Extrinsic motivation associates with: (1) external regulation like to chase reward or avoid punishment in learning; (2) introjected regulation such as prevent a bad situation or feeling guilty when learning; (3) identified regulation for instance learning a specific subject for a purpose; and (4) integrated regulation is doing self-analysis to reasons behind the learning.

\subsubsection{Amotivation}

Interestingly, there is also a condition where the absence of any motivation in learning known as amotivation. It is a result of unwillingness or lack motivation in learning. Learners with amovation or low motivation state feel unable to conduct learning processes. They assume that learning has no desired outcome and doing assignment has no value [25]. The Figure 1 is presented to illustrate a taxonomy of human motivation types by [12].

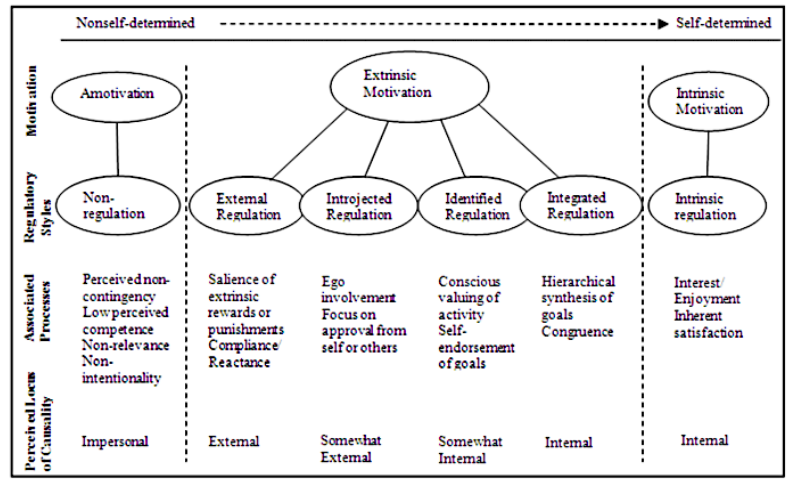

Figure 1. A Taxonomy of Human Motivation

\subsection{Motivation in Online Learning}

Students participate in online learning on the basis of their own responsibility and awareness for their own learning. The success of their online learning was associated with their motivation to gain new knowledge while making interaction with other students and teachers virtually [26][27]. Previous studies reported that students' motivation in online learning were mostly affected by their internal driven factors. The factors such as isolated feelings, technology incompetence, and failure in time management have contributed to the unsuccessful online learners [28][29]. However, getting more familiar to technology as they constantly participate in their virtual classes weaken their barriers. Hence, their intrinsic motivation has been recognised as stable personal characteristics for their successful online learning [30][31][32]. In addition, the absent of both intrinsic and extrinsic motivation or amotivation state is the most determining factor for the unsuccessfulness students' online learning [30]. 
In Indonesia, some studies revealed that students' motivation in participating their online classes amidst the Covid-19 pandemic era was influenced by both internal and external motivation factors. Intrinsically, the students were motivated in online learning due to interest to the subject, enthusiasm in learning activities, high commitment in learning new knowledge and skills, and persistence in conducting online learning activities [17][33][34]. Moreover, they were also extrinsically motivated die to the existence of proper supporting facilities i.e.: sufficient gadgets, good internet access, applicable learning platforms, technology savvy, and interesting learning activities [17][23][7][33][34].

\subsection{Online Learning}

The term online learning has been defined by some scholars. It is argued as learning with the use of web and internet [35]. It is also described as internet-based learning in which learners interact with learning materials, teachers and other learners to gain knowledge, and grow from the online learning experience [36]. Whereas, it is defined as a remote learning under technological gadgets in which the learners, instructors and institution are geographically separated [25].

During the Covid-19 pandemic era, 12.2 billion students are having online classes remotely using digital platforms [37]. Although online learning has been settled as a part of learning system, some education institutions are stunted in conducting fully online learning system due to insufficient supporting facilities in information and technology [38]. This sudden learning shift poses unplanned curriculum changes in which various learning applications are implemented in learning activities. Digital platforms like Google Meet, Cisco WebEx, and Zoom Cloud Meeting are used as teaching media. Learning materials are given online and assignments or examinations are conducted through a computer-based system [39].

\section{RESEARCH METHODOLOGY}

\subsection{Method}

This study applied quantitative research design to answer the research question. It was aimed to measure the variables of intrinsic factors (interest, encouragement, enjoyment, and satisfaction), extrinsic factors (external regulation, introjected regulation, identified regulation, and integrated regulation), and amotivation factors (perceived no-contingency, low perceived competence, non-relevance, and non-intentionality) of students' motivation in online learning during the Covid-19 pandemic era. Using descriptive analysis, it was also to describe the levels of variables, in this case, intrinsic and extrinsic factors [40].

\subsection{Place and Time}

Sriwijaya State Polytechnic was chosen purposefully as the site based on the need of the study. It was intended to know the students' motivation levels in online learning in a higher vocational institution. It was conducted for six months, from July - December 2021 of the academic year 2020-2021.

\subsection{Population and Sample}

The population of the study was all students of Sriwijaya State Polytechnic from any semester including both engineering and commerce majors. The sample was taken using random sampling in which 922 students participated in this study.

\subsection{Data Collection Technique}

The data were collected via a survey questionnaire about motivation in learning which reflected on SelfDetermination Theory of [12]. The survey questionnaire consisted of 12 questions of intrinsic, extrinsic, and amotivation factors with a 5-point Likert-scale. Due to physical restrictions during the Covid-19 pandemic, the survey questionnaire was distributed using Google Form.

\subsection{Data Analysis Technique}

The students' intrinsic, and extrinsic factors were narrated in positive meanings questions; hence they were measured using a 5-point Likert scale (1-strongly disagree (SD), 2-disagree (D), 3-neither agree nor disagree/neutral (N), 4-agree (A), 5-strongly agree (SA)). Meanwhile, amotivation factors were narrated in negative meaning questions, so they were measured in reverse way using a 5-point Likert scale $(5-\mathrm{SD}, 4-\mathrm{D}$, 3-N, 2-A, 1-SA). As suggested by [41], the Likertscale calculation formula used:

$$
\begin{aligned}
& \text { T x Pn } \\
& T=\text { Total Respondents } \\
& \text { Pn }=\text { Likert Scale Score }
\end{aligned}
$$

To find the interpretation of the Likert scale score, it needs to know the highest score $(\mathrm{Y})$ and the lowest score (X) by using formula:

$$
\begin{aligned}
& Y=\text { the highest Likert } \mathrm{x} \text { total respondents } \\
& \mathrm{X}=\text { the lowest Likert } \mathrm{x} \text { total respondents }
\end{aligned}
$$

Then the interpretation of students' motivation in online learning is gained using Index \% formula:

$$
\text { Index } \%=\text { Total Score/Yx100 }
$$

The result of index \%, then, was match to the Likertscale 5 points category intervals in Table 1 . Moreover, the data were describe using a descriptive analysis. 
Table 1. Index Percentage Interval

\begin{tabular}{|c|c|}
\hline Index $\%$ & Category \\
\hline $100 \%-80 \%$ & Excellent \\
\hline $79.9 \%-60 \%$ & Good \\
\hline $59.9 \%-40 \%$ & Sufficient \\
\hline $39.9 \%-20$ & Fair \\
\hline $19.9 \%-0 \%$ & Poor \\
\hline
\end{tabular}

\section{RESULTS AND DISCUSSION}

\subsection{Results}

Totally, there were 922 students as respondents participated in responding the online survey questionnaire. Their responses regarding their intrinsic, extrinsic, and amotivation factors toward their motivation in online learning during the Covid-19 pandemic era are presented in percentage.

\subsubsection{Intrinsic Factors}

Table 2 shows that the students intrinsically indicated to have good motivation toward their online learning. They had high satisfaction on it as $26.1 \%$ strongly agree and $41.2 \%$ agree, and $25.2 \%$ sufficient or neutral. For the enjoyment, $8.9 \%$ strongly agree and $25.1 \%$ agree, with $40.6 \%$ sufficient. Their interest was reported good for $10.1 \%$ strongly agree and $18.3 \%$ agree with $52.9 \%$ sufficient. However, the encouragement was slightly opposite from the first three factors because the disagree and strongly disagree are higher than the counterparts (44\%).

Table 2. The Intrinsic Factors Likert-scale Percentage

\begin{tabular}{|l|l|l|l|l|l|l|}
\hline No & \multicolumn{1}{|c|}{ Factor } & $\begin{array}{c}\text { SA } \\
(\%)\end{array}$ & $\begin{array}{c}\text { A } \\
(\%)\end{array}$ & $\begin{array}{c}\text { N } \\
(\%)\end{array}$ & $\begin{array}{c}\text { D } \\
(\%)\end{array}$ & $\begin{array}{c}\text { SD } \\
(\%)\end{array}$ \\
\hline 1 & Interest & 10.1 & 18.3 & 52.9 & 14.7 & 3.9 \\
\hline 2 & Encouragement & 3.9 & 8.6 & 43.4 & 35.4 & 8.6 \\
\hline 3 & Enjoyment & 8.9 & 25.1 & 40.6 & 21.5 & 3.9 \\
\hline 4 & Satisfaction & 26.1 & 41.2 & 25.2 & 5.6 & 2 \\
\hline
\end{tabular}

Figure 2 below shows that satisfaction was the highest internal factor for students' motivation in their online learning $(76.4 \%)$, following by interest $(67.7 \%)$ and enjoyment $(62.5 \%)$, and the least one was encouragement $(52.2 \%)$. Hence these first three factors can be categorised as good factors to contribute in students' motivation toward their online learning during the Covid19 pandemic era based on the index\% in Likert Scale. However, the last one, encouragement, was in sufficient factor category. The interpretation calculation of the intrinsic factors scores in index $\%$ is presented in Figure 2 .

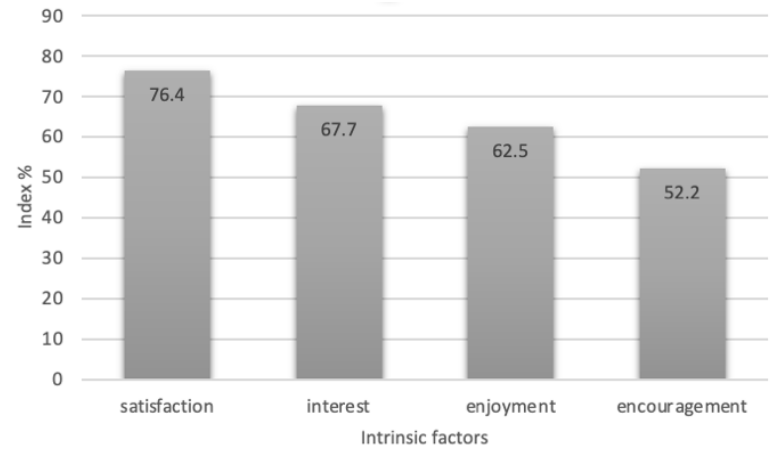

Figure 2. Index \% of Intrinsic Factors

\subsubsection{Extrinsic Factors}

The students' extrinsic factors impressively indicate in the Table 3. They were motivated highest in identified regulation with $32.4 \%$ strongly agree, $42.2 \%$ agree and $20.6 \%$ enough. The integrated regulation was also reported to have high influence as $24.8 \%$ of the students are strongly agree, $43.3 \%$ agree, and $27.1 \%$ sufficient. Both external and introjected regulations were also implied having good contribution. Their percentages in strongly agree and agree were more than $75 \%$.

Table 3. The Extrinsic Factors Likert-scale Percentage

\begin{tabular}{|l|l|c|c|c|c|c|}
\hline No & \multicolumn{1}{|c|}{ Factor } & $\begin{array}{c}\text { SA } \\
(\%)\end{array}$ & $\begin{array}{c}\mathrm{A} \\
(\%)\end{array}$ & $\begin{array}{c}\mathrm{N} \\
(\%)\end{array}$ & $\begin{array}{c}\mathrm{D} \\
(\%)\end{array}$ & $\begin{array}{c}\text { SD } \\
(\%)\end{array}$ \\
\hline 1 & $\begin{array}{l}\text { External } \\
\text { Regulation }\end{array}$ & 25.5 & 33.6 & 25.4 & 11.6 & 3.9 \\
\hline 2 & $\begin{array}{l}\text { Introjected } \\
\text { Regulation }\end{array}$ & 21.4 & 32.8 & 39 & 3.9 & 2 \\
\hline 3 & $\begin{array}{l}\text { Identified } \\
\text { Regulation }\end{array}$ & 32.4 & 42.2 & 20.6 & 3.9 & 1 \\
\hline 4 & $\begin{array}{l}\text { Integrated } \\
\text { Regulation }\end{array}$ & 24.8 & 43.3 & 27.1 & 3.7 & 1 \\
\hline
\end{tabular}

The following Figure 3 informs that all students' external factors in motivation toward their online learning were classified good. They were described to have decent principles in identified regulation (79.85), integrated regulation $(77.2 \%)$, introjected regulation (73.1\%), and external regulation (72.8). The interpretation calculation of the extrinsic factors scores in index $\%$ is presented in Figure 3.

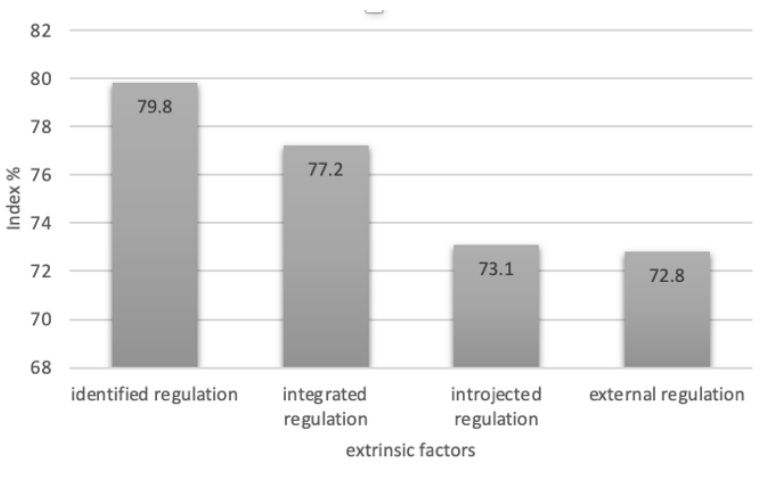

Figure 3. Index \% of Extrinsic Factors 


\subsubsection{Amotivation Factors}

It is also worthy to measure the students' amotivation factors because they also affect the motivation. As the amotivation questions had negative meanings, the measurement was reversed to the intrinsic and extrinsic factors measurement. Table 4 is displayed to show that the students were greatly shown to strongly disagree (40.6\%), disagree (14.3\%) and neutral $(32.4 \%)$ about their low-perceived competence and had no nonintentionally $(33.6 \%, 15.2 \%, 33.3 \%)$ in online learning. They also strongly disagreed $(36.8 \%)$ and disagreed $(10.7 \%)$ to their non-relevance amotivation factor. Nevertheless, the perceived non-contingency indicated contrary to the three previous factors, $19.6 \%$ students strongly disagreed, $6 \%$ disagreed, with $49.8 \%$ sufficient.

Table 4. The Amotivation Factors

\begin{tabular}{|c|l|l|l|l|l|l|}
\hline No & \multicolumn{1}{|c|}{ Factor } & $\begin{array}{c}\text { SA } \\
(\%)\end{array}$ & $\begin{array}{c}\text { A } \\
(\%)\end{array}$ & $\begin{array}{c}\text { N } \\
(\%)\end{array}$ & $\begin{array}{c}\text { D } \\
(\%)\end{array}$ & $\begin{array}{c}\text { SD } \\
(\%)\end{array}$ \\
\hline 1 & $\begin{array}{l}\text { Perceived non- } \\
\text { contingency }\end{array}$ & 5 & 19.8 & 49.8 & 19.5 & 6 \\
\hline 2 & $\begin{array}{l}\text { low perceived } \\
\text { competence }\end{array}$ & 2.9 & 9.7 & 32.5 & 40.6 & 14.3 \\
\hline 3 & non-relevance & 3.6 & 10.7 & 33.8 & 36.8 & 10.7 \\
\hline 4 & non-intentionality & 3.2 & 14.8 & 33.3 & 33.6 & 15.2 \\
\hline
\end{tabular}

As amotivation factors were measured in reverse way from the intrinsic and extrinsic factors, Figure 4 was implied that the students had fair amotivation factors. Their low perceived competence indicates the lowest factor (29.6\%), following by non-intentionality (31.6\%), non-relevance $(33.2 \%)$ and perceived non-contingency (39.4\%). Hence it was implicitly stated that students had no serious amotivation factors in their online learning during the Covid-19 pandemic era. The interpretation calculation of the amotivation factors scores in index \% is presented in Figure 4.

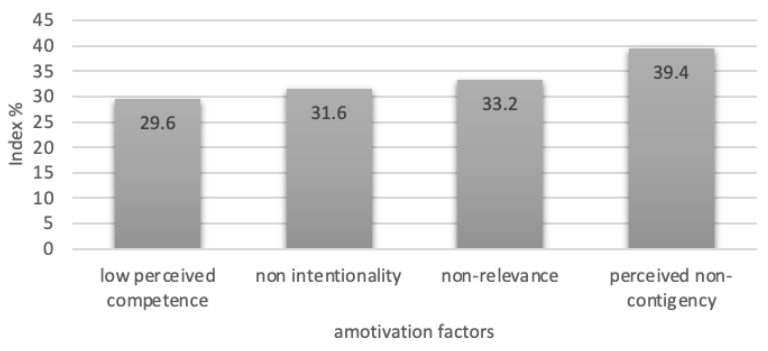

Figure 4. Index $\%$ of Amotivation Factors

\subsection{Discussion}

It has been revealed in the findings section that the students at Sriwijaya State Polytechnic toward their online learning during the Covid-19 pandemic era were more motivated by their external factors. This is in line with [9][11][8] that learners are more affected by their external factors. Their participation toward their online learning was the result of their autonomy or selfdetermination about the regulations in online learning [42]. The highest external motivation factor was identified regulation in which students were selfdetermined about their personal importance into the online learning. They participated to the virtual learning activities because they saw it as values of one of their life goals [43][44]. As the students had proper identified regulation, they were able to integrate the values to the needs of their online learning. The integrated regulation made them fully understand and enable to do selfanalysis the reasons behind their online learning. Moreover, the students were motivated by their egoenhancement to avoid the feelings of guilty and anxiety. They joined their online classes just because to avoid shyness and punishment from being absent as the form of their introjected regulation [24][45]. The least students' self-determined external motivation factor was external regulation. This external regulation as the least extrinsic motivation. The behaviour was done to gain reward or satisfaction on external need [24].

The students were also driven by their internal factors in online learning i.e.: satisfaction, enjoyment, interest, and encouragement. As argued by some scholars, that good internal factors as constant personalities drive their learning activities into successful online learners [30][31][32][17][8]. In this study, satisfaction as the highest internal factor was assumed to facilitate the students in their online learning. The feeling of satisfaction in term of being able to accomplish and complete the learning activities motivate their participation in online learning [24]. The other internal factors were interest and enjoyment. The curiosity and pleasure to learn new material remotely using digital technology affected their self-determination in conducting their online learning. However, the students' encouragement had least effect to their motivation. Due to some delays and problems in virtual interaction like lagging or freezing connection, this caused frustration and hindrance their comprehension toward the online learning material [28][29][30].

Interestingly, still, percentage of amotivation factors: low perceived competence, non-intentionality, nonrelevance, and perceived non-contingency. The absent of both extrinsic and extrinsic motivation factors gave very small contribution to students' enthusiasm in online learning. Amotivation is the results of failure in valuing, feeling competence, and believing in the online learning activities [24]. However, it is argued because ethe condition of poor external factors which is in turn, affected the demotivated students' belief and selfdetermination level [46]. 


\section{CONCLUSION}

The students' motivation factors both internal and external have been acknowledged to give influence toward their online learning. This study unveiled the students at Sriwijaya State Polytechnic were more motivated via their extrinsic factors in their online learning comparing to the intrinsic ones. They were properly self-determined by their identified regulation, integrated regulation, external regulation, and introjected regulation. Furthermore, their intrinsic motivation factors, like satisfaction, interest, and enjoyment were indicated giving appropriate contribution to their online learning processes. However, one intrinsic factor, namely encouragement, gave the least contribution. Hence, it is recommended for the institution and lecturers to situate more consideration in this factor as it also related to students' success in online learning. In addition, it is recommended to have more related studies in the future with more participants and more comparative research topics like students' genders and majors or departments.

\section{ACKNOWLEDGMENT}

Our highly gratitude is extended to Sriwijaya State Polytechnic for approving and funding this study.

\section{REFERENCES}

[1] Ministry of Education and Culture of the Republic of Indonesia. (2020). Circular Letter No. 4 of 2020 about the Implementation of Education Policy in the Emergency Period Spreading of Corona Virus Disease (COVID- 9). Jakarta, Indonesia: Ministry of Education and Culture.

[2] Dasrun, H. \& Noeraida. (2020). Pengalaman Komunikasi Siswa Melakukan Kelas Online Selama Pandemi Covid-19. (Online). 3 (2). 172-182

[3] Firman, F., \& Rahayu, S. (2020). Pembelajaran Online di Tengah Pandemi Covid-19. Indonesian Journal of Educational Science (IJES), 2(2), 81-89.

[4] Hidayat, D., \& Noeraida, N. (2020). Pengalaman Komunikasi Siswa Melakukan Kelas Online Selama Pandemi Covid - 19. JIKE: Jurnal Ilmu Komunikasi Efek, 3(2), 172- 182.

[5] Khasanah, D. R. A. U., Pramudibyanto, H., \& Widuroyekti, B. (2020). Pendidikan dalam Masa Pandemi Covid-19. Jurnal Sinestesia, 10(1), 41-48.

[6] Pakpahan, R., \& Fitriani, Y. (2020). Analisa Pemanfaatan Teknologi Informasi Dalam Pembelajaran Jarak Jauh di Tengah Pandemi Virus Corona Covid-19. Journal of Information System, Applied, Management, Accounting and Research, 4(2), 30-36.
[7] Rochman, C., \& Pertiwi, C. S. R. (2020). Learning at Covid-19 Pandemic Era: Science Technology Engineering and Mathematic Competencies and Student Character. Science Education Journal, 4(2), 129-42.

[8] Simamora, R.M. (2020). The Challenges of Online Learning during the COVID-19 Pandemic: An Essay Analysis of Performing Arts Education Students. Journal of Studies in Learning and Teaching, 1(2), 86-103.

[9] Cahyani, A., Listiana, I. D., \& Larasati, S. P. D. (2020). Motivasi Belajar Siswa SMA pada Pembelajaran Daring di Masa Pandemi Covid-19. Jurnal Pendidikan Islam, 3(1), 123-140.

[10] Gustiani, S. (2020). Students' Motivation in Online learning during Covid-19 Pandemic Era: a case study. Holistics 12(2), 23-40.

[11] Rachmat, N. (2020). Analysis of Effectiveness of Online Learning Pandemic Covid-19 in Prosthetic Orthotic Major in Polkesta. Jurnal Terpadu Ilmu Kesehatan, 9(2), 117-268.

[12] Deci, E. L., \& Ryan, R. M. (1985). Intrinsic motivation and self-determination in human behavior. New York: Plenum.

[13] Brophy, J. (2010). Motivating students to learn (3rd ed.). New York, NY: Routledge.

[14] Deci, E. \& Ryan, R. (2000). The "What" and "Why" of Goal Pursuits: Human Needs and theSelfDetermination of Behaviour. Psychological Inquiry, 11, 227-268.

[15] Schunk, D. H., \& Usher, E. L. (2012). Social cognitive theory and motivation. In R. M. Ryan (Ed.), The Oxford handbook of human motivation (pp. 13-27). Oxford, UK: Oxford University Press.

[16] Topalov, J. (2011). Motivacija u nastavi stranog jezika. Novi Sad: Prosveta.

[17] Fitriyani, Y., Fauzi, I., \& Sari, M. Z. (2020). Motivasi belajar mahasiswa pada pembelajaran daring selama pandemic Covid-19. Jurnal Kependidikan: Jurnal Hasil Penelitian dan Kajian Kepustakaan di Bidang Pendidikan, Pengajaran dan Pembelajaran, 6(2), 165- 175.

[18] Marwa, A., al Nabiil, A. R., \& Syuhadak. (2021). Motivation Problematics of Arab Learners During Covid-19 Pandemic. Jurnal Al Bayan: Jurnal Pendidikan Bahasa Arab, 13(2), 268-285.

[19] Lopez, M. A., Fransisco, C. D., Capinig, C., Alayan, J., Manolo, S., \& Tus, J. (2021) Amidst Covid-19 pandemic: The self-efficacy and academic achievement motivation of the college students from 
the private higher education institution in the Philippines.

[20] Adnan, M. (2020). Research Article Online learning amid the COVID-19 pandemic: Students' perspectives. Journal of Pedagogical Sociology and Psychology, 2(1), 45-51. https://doi.org/10.33902/JPSP.CITATION

[21] Agung, A. S. S. Nu., Surtikanti, M. W., \& OP, C. A. Q. (2020). Students' Perception of Online Learning during COVID-19 Pandemic : A Case Study on the English Students of STKIP Pamane Talino. SOSHUM Jurnal Sosial Dan Humaniora [Journal of Social Sciences and Humanities], 10(2), 225-235.

[22] Irawan, A. W., Dwisona, \& Lestari, M. (2020). 1 , 1, 3 1. KONSELI: Jurnal Bimbingan Dan Konseling (E- Journal) Psychological, 07(1), 53-60.

[23] Laili, R. N. \& Nashir, M. (2021). Higher education students' perception on online learningduring Covid-19 pandemic. Edukatif: Jurnal Ilmu Pendidikan 3(3), 689-697.

[24] Ryan, R., \& Deci, E. (2000a). Intrinsic and extrinsic motivations: classic definitions and new directions. Contemporary Educational Psychology, 25(1), 5467.

[25] Harnett, M. (2016). Motivation in Online Education. Singapore: Springer Nature. doi:10.1007/978-98110-0700-2.

[26] Knowles, E. \& Kerkman, D. (2007). An investigation of students' attitude and motivation toward online learning. Insight: A Collection of Faculty Scholarship-Student Motivation, 2, pp. 7080. USA.

[27] Schunk, D. H., Meece, J. L., \& Pintrich, P. R. (2014). Motivation in education: Theory, research, and applications (4th ed.). Boston, MA: Pearson.

[28] Hara, N., \& Kling, R. (2003). Students' distress with a web-based distance education course: An ethnographic study of participants' experiences. Turkish Online Journal of Distance Education, 4(2). http://tojde.anadolu.edu.tr/tojde10/articles/hara.htm

[29] Paulus, T., \& Scherff, L. (2008). "Can anyone offer any words of encouragement?" Online dialogue as a support mechanism for preservice teachers. Journal of Technology and Teacher Education, 16(1), 113136.

[30] Keller, J. M. (2008). First principles of motivation to learn and e3-learning. Distance Education, 29(2), 175-185. doi:10.1080/01587910802154970.

[31] Wighting, M. J., Liu, J., \& Rovai, A. P. (2008). Distinguishing sense of community and motivation characteristics between online and traditional college students. Quarterly Review of Distance Education, 9(3), 285-295.

[32] Yukselturk, E., \& Bulut, S. (2007). Predictors for student success in an online course. Educational Technology \& Society, 10(2), 71-83. Retrieved from http://www.ifets.info/.

[33] Sudarmo, Nugraha, M. S., Mardhiah, Liow, F. E. R.I., \& Aslan, (2021). The identification on online strategy results while students learn from home during the disruption of the Covid-19 Pandemic in Indonesia. Journal of Contemporary Issues in Business and Government, 27(2), 1950-1956.

[34] Syauqi, K., Munadi, S., \&Triyono, M. B. (2020). Students' perception towards vocational education on online learning during the Covid-19 pandemic. International Journal of Evaluation and Research in Education (IJERE), 9(4), 881-886.

[35] Bates, A. W. (2005). Technology, e-learning and distance education (2nd ed.). New York: Routledge Falmer.

[36] Ally, M. (2008). Foundations of educational theory for online learning. In T. Anderson (Ed.), Theory and practice of online learning (2nd ed., pp. 3-31). Retrieved from http://www.aupress.ca/ index.php/books/120146.

[37] Li, C., \& Lalani. F. (2020, April 29). The COVID19 pandemic has changed education forever. This is how. World Economic Forum. https:// www.weforum.org/agenda/2020/04/coronaviruseducation-global-covid19-online-digital-learning/

[38] United Nations Sustainable Development Group. (2020). Policy brief: Education during COVID-19 and beyond. United Nations Sustainable Development Group. https://unsdg.un.org/ sites/default/files/2020-08/sg_policy_brief_covid19_and_education_august_2020.pdf

[39] Khalil, R., Mansour, A. E., Fadda, W. A., Almisnid, K., Aldamegh, M., Al-Nafeesah, A., Alkhalifah, A., \& Al-Wutayd, O. (2020). The sudden transition to synchronized online learning during the COVID-19 pandemic in Saudi Arabia: a qualitative study exploring medical students' perspective. BMC Medical Education 20(285).

[40] Creswell, J. W. (Eds.). (2012). Educational research: planning, conducted and evaluating quantitative and qualitative research. Boston, MA: Pearson.

[41] Nazir, M. (2005). Metode Penelitian. Bogor: Ghalia Indonesia. 
[42] Ryan, R. M., \& Deci, E. L. (2000b). Selfdetermination theory and the facilitation of intrinsic motivation, social development, and well-being. American Psychologist, 55(1), 68-78. doi:10. 1037/0003-066X.55.1.68.

[43] Erten, I. H. (2014). Interaction between academic motivation and student teachers' academic achievement. Procedia-social and Behavioral Sciences 152(2014), 173-178.

[44] Ryan, R. M., \& Deci, E. L. (2002). Overview of selfdetermination theory: An organismic dialectical perspective. In E. L. Deci \& R. M. Ryan (Eds.),
Handbook of self-determination research (pp. 333). Rochester, NY: University of Rochester Press.

[45] Chen, K.C., \& Jang, S. J. (2010). Motivation in online learning: Testing a model of selfdetermination theory. Computers in Human Behavior Journal, 26, 741-752.

[46] Lepper, M. R., Henderlong Corpus, J., \& Iyengar, S. S. (2005). Intrinsic and extrinsic motivational orientations in the classroom: Age differences and academic correlates. Journal of Educational Psychology, 97(2), 184-196. doi:10.1037/00220663.97.2.184. 